\title{
Defining social content and social content management: service science perspective
}

\author{
Wan Azllin Zurita Wan Ahmad ${ }^{1}$, Muriati Mukhtar ${ }^{2}$, Yazrina Yahya ${ }^{3}$ \\ ${ }^{1,2}$ Faculty of Information Science and Technology, Universiti Kebangsaan Malaysia, Malaysia \\ ${ }^{3}$ Faculty of Economy and Management, Universiti Kebangsaan Malaysia, Malaysia
}

\begin{tabular}{l} 
Article Info \\
\hline Article history: \\
Received Jul 13, 2019 \\
Revised Sep 14, 2019 \\
Accepted Sep 26, 2019 \\
\hline
\end{tabular}

Keywords:

DART model

Service dominant logic

Service science

Social content

Social content management

Social media

\begin{abstract}
Social media enables unlimited open interactions between organisations and customers. Social content resulting from social media interactions are of immense value and could be beneficial to both organisations and customers. Well managed social content could be used as a basis for producing service innovations offered by the organisations. However, the meaning of social content and its definition is not clearly articulated in the literature. This led to an equally limited meaning of social content management. In this regard, this article proposed that the definition of social content and social content management should be developed from the service science perspective. This is necessary to capture the essential facet of social interactions, that of value co-creation. Both definitions are developed through a triangulation process namely, literature review and a series of interviews with experts. With the proposed definition of social content and social content management, it is hoped that it would enhance the understanding of both concepts thus leading to a more effective way of managing social content.
\end{abstract}

Copyright $(0) 2020$ Institute of Advanced Engineering and Science. All rights reserved.

\section{Corresponding Author:}

Wan Azlin Zurita Wan Ahmad,

Faculty of Information Science and Technology,

Universiti Kebangsaan Malaysia, Malaysia.

Email: azlinzurita@gmail.com

\section{INTRODUCTION}

Social media is fast becoming a new way of communication. A recent study reported that users tend to spend between two to five hours per day on social media [1], and use social media for daily activities [2]. It is thus not surprising that social media has now become a new platform for customers to find information compared to newspapers and other mainstream media [1], and to get closer to organisations [3, 4]. Organisations have also adopted social media as a source of information acquisition and tools for engaging with the customers to gain insights on the real needs of the customers. Via social media, customers could openly express their feelings, thus making the platform as the best way to engage with the organisations [3,5]. Social media also promotes social capital [6]. Open interactions on social media platform between organisations and customers give rise to a plethora of content. The content, which is cocreated between organisations and customers, is named as social content. Social content needs to be managed accordingly so that meaningful insights could be obtained from them. These insights could lead to new value offerings and innovative services from the organisations [7-10].

However, the understanding of social content is still unclear, and the definitions for social content is still limited. [11] stated that social content is closely related to collaboration and content sharing within the organisation. Besides that, based on [12], social content is defined as "unstructured data generation through social channels and processes for human use". Social content is derived from enterprise-managed blogs and wikis or through an externally hosted environment such as Facebook and Twitter, that is used for content sharing and collaborating that supports the organisation [12]. Based on the existing definition, it is found that 
only the human component and the channel are described, whereby other components could also be considered in the definition of social content.

Apart from the definition of social content, the meaning and discussion on social content management are given less attention in the academic mainstream. The term of social content management was triggered by [13], who defines social content management as "a set of concepts, methodologies and standards that facilitate the production, organisation and retention of social content". Considering that the definition by [13] is micro definition, [7] improved the definition of social content management as "dynamic management of all aspects of social content whether internal or externally that includes data, technology, processes, humans and organisations to create and maintain sustainable value to the organisation". Besides that, [12] stated that social content management is closely related to a system of engagement that involves people and process to deliver valuable content. However, this definition is characterized by the needs of the organisations which need to be aligned to the needs of the customers who are also one of the critical components of social media interaction. Social media also facilitates the value co-creation process between the organisations and the customers. In developing the definition of social content and social content management that consider the value co-creation between organisations and customers, both definitions could be seen through a different point of view namely from the perspective of service science.

Service science is an interdisciplinary field that examines and explains how service systems interact as well as mutually creates value [14]. Service science perspective could highlight the value co-creation, namely the value gained by the organisations and the customers [15-17]. Value co-creation is essential in providing product or services that emphasises on value to both parties [17-19]. This is suitable for the nature of social media that ease the process of value co-creation from the interactions of various actors [20]. Service science puts suitable priority on the concepts of value co-creation which are embodied in the servicedominant logic (SD-L). SD-L is the contrast of "goods-dominant logic", giving attention to the component of service, and its importance in the exchange and competitive level of the organisations against their rival [17]. Social content resulting from social media interaction creates the customer-generated content, which is used by the organisations to improve the quality of services offered by the organisation based on the customers' needs. This is evidenced by the study by [21], that reveals the social content could assist in understanding the main components of customer brand engagement that could foster the intentions of the customer in purchasing the brand. Besides that, a study by [22] reveals that social content could bring the business opportunity to the organisations with the privilege of social media that offers the responsibility and control of content to the customer. With the importance of social content in innovating services of the organisation, thus it is making sense that service science perspective is suitable as a basis to develop the definitions of social content and social content management.

The previous study on service science perspective highlight the elements and factors that should be considered in managing social content. The elements and factors could be a guide in defining the social content and social content management from the perspective of service science. Hence, studies by [9, 10] explained the elements and factors as in Figure 1. From Figure 1, the essential elements in managing social content are "actor", "resource integration", "service exchange", "institution and institutional arrangement" and "service ecosystem". Literature review in service science perspective affirms on actor involvement in service exchange and resource integration [17]. Besides that, the overall process of value co-creation indicates the importance of institutions and institutional arrangements and its execution on a sound environmental ecosystem [17]. Therefore, the definition of social content and social content management based on service science perspective is developed based on the understanding of those concepts. 


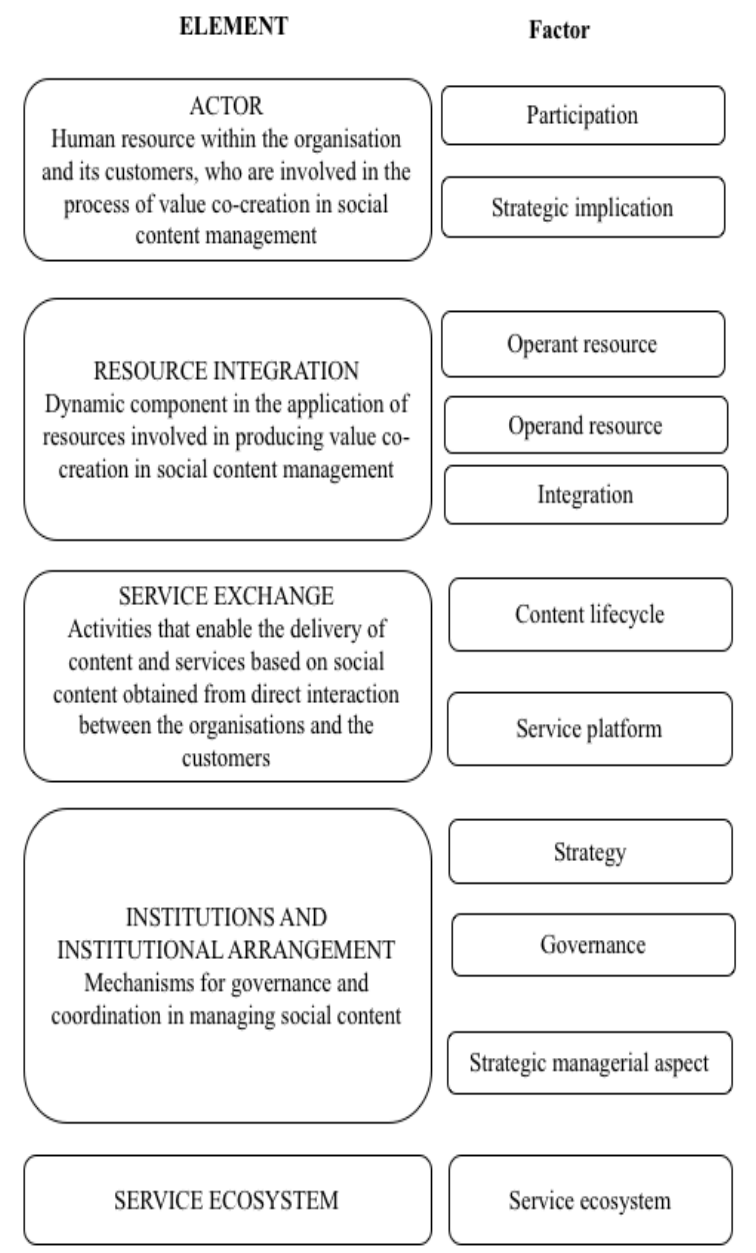

\author{
Description \\ Involvement and engagement of human resources while managing social content \\ Main effects resulted from the participation of actors in social content management
}

Dynamic resource in social content management that is meant to increase the competitiveness of organisations (referring to the skills, capabilities, knowledge) Static resource involved in social content management (such as tools, technology, budget, manpower)

Relationship between various sources namely human resources and content assets in social content management

Process of monitoring social content starting from capturing up to the maintaining, to support value co-creation process between organisations and customers

Space of interaction in managing social content to increase the efficiency of service exchange (such as systems)

Planning, measures and methods in the management of social content to meet the needs of the organisations and the customers

Administrative routine for controlling the social content management in order to ensure the integrity of the content, which involves various human resources and content assets

Acceptance of the actors to changes in technology, administration and content management methods and the increase in the level of competence of actors

Holistic environment that allows the value co-creation process to take place in the social content management

Figure 1. Elements and factors of social content management based on service science perspective source : $[9,10]$

\section{METHOD}

This study used two methods in developing the definition of social content and social content management based on service science perspective, namely content analysis for the literature review, and text analysis for the interview. For both methods, repeating statements or similar meanings are merged under one code or theme. The steps adopted for literature review is based on [23]. Detailed explanations for each step are as follows:

1. Prepare Raw Data

For a literature review, document search was conducted on the research database, other database, and the appropriate site, by using keywords. Keywords used in this study were "enterprise content management", "social content management", "social media content management" "social media management", "service science", "service-dominant logic", and "DART model". Only documents written in Malay and English were selected in this phase. As a triangulation step towards the results obtained through a literature review, a series of interview sessions were conducted with five informants. The selected informants were from the category of ICT Expert (Information Management) in the Malaysian Public Sector and Public Relation Officer (PRO). Both categories of informants are individual who involves directly in managing social content. The list of informants is shown in Table 1. 
Table 1. List of Informants

\begin{tabular}{|c|c|c|}
\hline Informant ID & Position and Experience & Interview Lenght \\
\hline TA2 & $\begin{array}{l}\text { His current position is ICT Experts in Information Management. He sits at the tactical level } \\
\text { of management, with } 26 \text { years of experience. He has broad expertise as ICT Managers in } \\
\text { four organisations, and Leader for project related to system development, information } \\
\text { management and content management. }\end{array}$ & 1 hour \\
\hline TA4 & $\begin{array}{l}\text { Her current position is PRO. She sits at the operational level of management, with } 13 \text { years } \\
\text { of experience. She has the vast experience as the PRO and team leader for PRO who } \\
\text { manage all media channel in the organisation, including social media. }\end{array}$ & 1 hour \\
\hline
\end{tabular}

2. Step 1: Preparing for data analysis

Involves the preparation of the study material, which includes the activities of, (1) scanning the contents of the selected documents, and (2) manually transcribed the result of interviews.

3. Step 2: Reading data

Involves reading and exploring the study material. For the literature review, document analysis was conducted on the material sought during the "Prepare raw material" phase. For the interviews, text analysis was carried out to transcribe the dialogues collected during Step 1. Text analysis was carried out by examining the dialogue by informants tailored to the results obtained by the content analysis of the literature review.

\section{4. $\quad$ Step 3: Coding data}

Involves compiling the data to appropriate fractions. This study used the Tesch eight-step set in [23] for coding the data which is (1) reading the material as a whole and recording the ideas that suit with the needs of the study, (2) selecting a material and reviewing it in detail, (3) listing topics and creating clusters on the same topic, (4) developing the initial code (based on identified topics), (5) identify descriptive words to illustrate identified codes, (6) make final decisions for code, (7) compile data to the preset code, and (8) reencoding (if necessary). Aside from that, based on [23], there are also issues related to code development, namely (1) code based on a combination of data collected from the material, (2) code based on predetermined code and customized data based on the code, or (3) combine these two coding methods. Hence, this study built the code manually through issue no (1) which is coding data based on the combination of data collected from the collected materials.

5. Step 4: Setting theme and setting description

Involves themes and explanations to themes to justify the theme's needs. Based on [24], the definition of content management should contain "who is involved?" and "how it was done?". Considering the meaning of social content is still unclear, the definition of social content is developed to support the definition of social content management. Development of the definition of social content also refers to [24] tailored to the context of social content. The identified code was categorized into the appropriate theme as in Table 2.

Table 2. Code and Theme for the Definition

\begin{tabular}{clc}
\hline Definition & Code & Theme \\
\hline Social content & Who is involved? & Definition \\
& How it was done? & \\
Social content management & Who is involved? & Definition \\
& How it was done? & \\
\hline
\end{tabular}

6. Step 5: Interrelating the theme and description

Involves on "how" the themes and explanations were linked.

7. Step 6: Interpreting the meaning of the theme

Involves the interpretation of the results of the study, which is lessons learned in obtaining the data appropriate to the context of the study. 
8. The validity of information accuracy [23] also emphasises the accuracy of the information for the validity of the results obtained. Therefore, two strategies were adopted in validating the accuracy of the information in this study namely:

a. Data collection was obtained through a variety of sources, namely literature review and a series of interviews.

b. Peer-review was conducted via research group discussion, and comments from the editor from proceeding and journal publication.

\section{RESULTS AND DISCUSSION}

Results and discussion consist of three subsections, namely the generic result and analysis of the dialogue, the definition of social content, and the definition of social content management.

\subsection{Generic Result and Analysis of the Dialogue}

As stated in Section 1: Introduction, past research in service science perspective giving attention on two perspectives namely (1) actor involvement in service exchange and resource integration, and (2) the overall process of value co-creation expresses the importance of institutions and institutional arrangements and its execution on a sound environmental ecosystem. Therefore, for the definition of social content is according to perspective (1), while the definition of social content management is conforming to perspective (2) to indicate the importance of the overall process. For interview sessions, all informants state their agreement with the "code" and "theme" as in Table 2, namely "Who is involved?" and "How it was done?" for both definitions. Informants provide comment on relevant matters (where appropriate). The dialogue from interviews is transcribed, analysed, and tabulated as in Table 3.

Table 3. Results and Analysis of the Dialogue

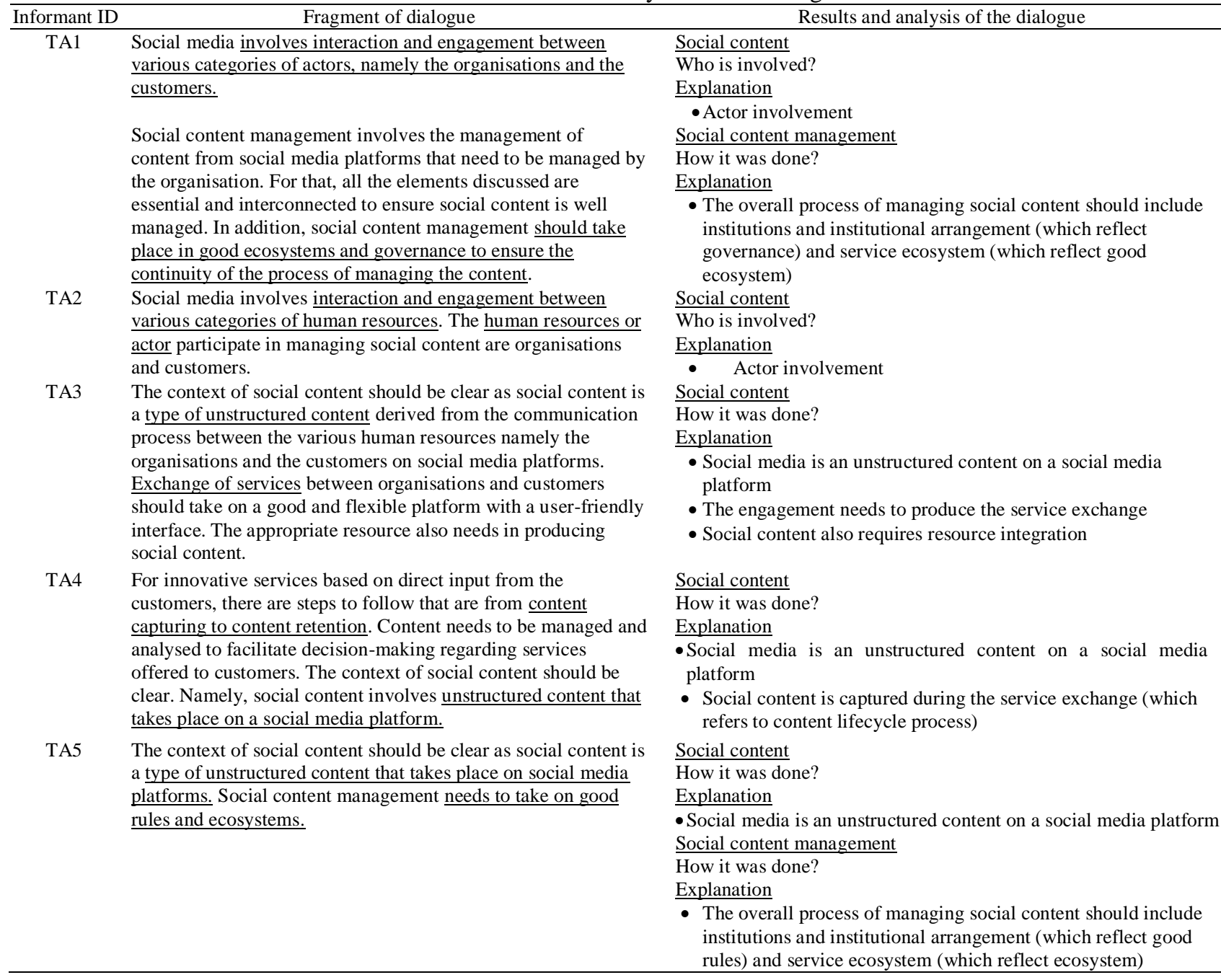

Defining social content and social content management: service science... (Wan Azllin Zurita Wan Ahmad) 


\subsection{The Definition of Social Content}

Table 4 shows the results based on the literature review on service science perspective and current definition of social content in Section 1 Introduction, and interview for the definition of social content in Table 3.

Table 4. Results based on Literature Review and Interview for the Definition of Social Content

\begin{tabular}{|c|c|c|c|c|c|}
\hline \multirow[t]{2}{*}{ Theme } & \multirow[t]{2}{*}{ Code } & \multicolumn{2}{|c|}{$\begin{array}{c}\text { Literature finding as in Section } \\
\text { 1: Introduction }\end{array}$} & \multirow{2}{*}{$\begin{array}{l}\text { Interview } \\
\text { finding } \\
\text { Informan } \\
\text { ID }\end{array}$} & \multirow[t]{2}{*}{ Justification } \\
\hline & & $\begin{array}{c}\text { Service } \\
\text { science } \\
\text { perspective } \\
\end{array}$ & $\begin{array}{c}\text { Current } \\
\text { definition on } \\
\text { social content }\end{array}$ & & \\
\hline \multirow[t]{2}{*}{ Definition } & $\begin{array}{l}\text { Who is } \\
\text { involved? }\end{array}$ & $\begin{array}{l}\text { Actor } \\
\text { participation } \\
{[17]}\end{array}$ & & $\begin{array}{l}\text { TA1 } \\
\text { TA2 }\end{array}$ & $\begin{array}{l}\text { In the service science perspective, the actors involved are } \\
\text { service providers (in the context of the study is } \\
\text { organisations) and customers. } \\
\text { This was agreed during the interview sessions, which stated } \\
\text { that social media and the management of social content } \\
\text { involves various actors, namely the organisations and the } \\
\text { customers. }\end{array}$ \\
\hline & $\begin{array}{l}\text { How it } \\
\text { was } \\
\text { done? }\end{array}$ & $\begin{array}{l}\text { Resource } \\
\text { integration } \\
\text { and service } \\
\text { exchange } \\
{[17]}\end{array}$ & $\begin{array}{l}\text { The type of } \\
\text { unstructured } \\
\text { content, } \\
\text { generate on } \\
\text { social media } \\
\text { channels, and } \\
\text { process for } \\
\text { human use [25] } \\
\text { Collaboration } \\
\text { and sharing [11] }\end{array}$ & $\begin{array}{l}\text { TA3 } \\
\text { TA4 } \\
\text { TA5 }\end{array}$ & $\begin{array}{l}\text { Based on literature review, social media is a type of } \\
\text { unstructured content generated on the social media } \\
\text { platform. This supports the current definition of social } \\
\text { content, "the type of unstructured content". } \\
\text { Also, based on interview sessions for "Collaboration and } \\
\text { sharing" context, the process should be performed on a } \\
\text { social media platform that involves the exchange of } \\
\text { services and resource integration. This coincides with a } \\
\text { service science perspective that focuses on resource } \\
\text { integration and service exchange. }\end{array}$ \\
\hline
\end{tabular}

Therefore, based on the explanation in Table 4, this study defines social content as:

"Unstructured content resulted from the active interaction of actors namely organisations and customers on social media platforms through the service exchange and resource integration."

\subsection{The Definition of Social Content Management}

As stated in Section 1: Introduction, the elements that should be considered in the definition of social content management are "actor", "resource integration", "service exchange", "institutions and institutional arrangement", and "service ecosystem" (see Figure 1). However, the definition of social content considers the element of "actor", "service exchange", and "resource integration". In this study, the term "social content" is embedded in the definition of social content management as a strong factor. In the "management" context, approached by [7] is applied in this study, namely the term "dynamic" in managing social content. Based on the literature review, as stated in subsection 3.1, the whole concept is focusing on institutions and institutional arrangement on a sound environmental ecosystem. Therefore, the definition of social content management follows service science literature. Table 5 shows the results based on the literature review on service science perspective and current definition of social content management (as in Section 1: Introduction), and interview for the definition of social content management (as in Table 3).

Table 5. Results based on Literature Review and Interview for the Definition of Social Content Management

\begin{tabular}{|c|c|c|c|c|c|}
\hline \multirow[t]{2}{*}{ Theme } & \multirow[t]{2}{*}{ Code } & \multicolumn{2}{|c|}{ Literature finding as in Section 1: Introduction } & \multirow{2}{*}{$\begin{array}{l}\text { Interview } \\
\text { finding } \\
\text { Informan } \\
\text { ID }\end{array}$} & \multirow[t]{2}{*}{ Justification } \\
\hline & & $\begin{array}{l}\text { Service science } \\
\text { perspective }\end{array}$ & $\begin{array}{l}\text { Current definition on social content } \\
\text { management }\end{array}$ & & \\
\hline \multirow[t]{3}{*}{ Definition } & $\begin{array}{l}\text { Who is } \\
\text { involved? }\end{array}$ & Not included & & \multirow{3}{*}{$\begin{array}{l}\text { TA1 } \\
\text { TA5 }\end{array}$} & $\begin{array}{l}\text { The term "social content" is } \\
\text { included as part of the } \\
\text { definition of social content } \\
\text { management. }\end{array}$ \\
\hline & $\begin{array}{l}\text { How it was } \\
\text { done? }\end{array}$ & $\begin{array}{l}\text { Institutional and } \\
\text { institutional } \\
\text { arrangements is } \\
\text { facilitating the } \\
\text { management }\end{array}$ & $\begin{array}{l}\text { A set of concepts, methodologies and } \\
\text { standards that facilitate the production, } \\
\text { organisation and retention of social } \\
\text { content [13] }\end{array}$ & & $\begin{array}{l}\text { Based on interview sessions } \\
\text { informant also stated the } \\
\text { importance of mechanisms to } \\
\text { govern the management of } \\
\text { social content as well as a }\end{array}$ \\
\hline & & $\begin{array}{l}\text { process. Besides } \\
\text { that, the service } \\
\text { ecosystem } \\
\text { involves holistic }\end{array}$ & $\begin{array}{l}\text { A dynamic management of all aspects of } \\
\text { social content whether internal or } \\
\text { external that includes data, technology, } \\
\text { processes, humans and organisations to }\end{array}$ & & holistic and good ecosystem. \\
\hline
\end{tabular}


Therefore, based on the explanation in Table 5, this study defines social content management as: "The dynamics process of social content that is governed by the institutions and institutional arrangement and progress on service ecosystem to produce service innovation."

\section{CONCLUSION}

This article develops the definition of social content and social content management based on service perspective to create a deeper understanding of both contexts. Service science perspective is chosen in developing both definitions as a fundamental theory to consider the value co-creation which benefits the organisations and the customers. In this study, social content is defined as "Unstructured content resulted from the active interaction of actors namely organisations and customers on social media platforms through the service exchange and resource integration". Meanwhile, social content management is defined as "The dynamics process of social content that is governed by the institutions and institutional arrangement and progress on service ecosystem to produce service innovation". For future work, the understanding of the definition of social content, social content management, and appropriate elements and factors could form a strategic framework to manage social content.

\section{ACKNOWLEDGEMENTS}

This research was supported by the Ministry of Education Malaysia under the Research Grant FRGS/2/2014/ICT01/UKM/02/1, Universiti Kebangsaan Malaysia and Public Service Department of Malaysia.

\section{REFERENCES}

[1] Salman Ali, Mohd Azul Mohamad Salleh, Mohammad Agus Yusoff, and M. Y. H. Abdullah, "Political engagement on social media as antecedent for political support among voters in Malaysia," J. Komunikasi, Malaysian J., vol. 34, no. 2, pp. 152-165, 2018.

[2] R. Arianto, H. L. H. Spits Warnars, E. Abdurachman, Y. Heryadi, and F. L. Gaol, "The architecture social media and online newspaper credibility measurement for fake news detection," Telecommun. Comput. Electron. Control, vol. 17, no. 2, pp. 738-744, 2019.

[3] M. A. Mohd Sani, S. Hassan, M. K. Ahmad, and Kartini Aboo Talib Khalid, "Generation Y's Political Participation and Social Media in Malaysia," Malaysian J. Commun., vol. 32, no. 1, pp. 125-143, 2016.

[4] M. H. T. Abdullah, A. L. Ahmad, and C. P. Kee, "The Exposure of Media Frames Among Malaysian Bloggers Pre and Post 13 Th General Election," J. Komun., vol. 32, no. 2, pp. 425-452, 2016.

[5] J. J. Stephen and P. P, "Detecting the magnitude of depression in Twitter users using sentiment analysis," Int. J. Electr. Comput. Eng., vol. 9, no. 4, pp. 3247-3255, 2019.

[6] M. Shanmugam, V. Karunakaran, and A. Amidi, "Formulation of an integrated social commerce framework to promote social capital for energy sectors," Indones. J. Electr. Eng. Comput. Sci., vol. 15, no. 1, pp. 427-434, 2019.

[7] A. M. Aladwani, "The 6As model of social content management," Int. J. Inf. Manage., vol. 34, no. 2, pp. 133-138, Apr. 2014.

[8] A. Herbst and J. vom Brocke, "Social content management systems: Challenges and potential for organizations," in Lecture Notes in Information Systems and Organisation, 2013, pp. 19-28.

[9] W. A. Z. W. Ahmad, M. Mukhtar, and Y. Yahya, "Validating the Social Content Management Framework: A Delphi Study," J. Pengur., vol. 53, pp. 1-20, 2018.

[10] W. A. Z. W. Ahmad, M. Mukhtar, and Y. Yahya, "Developing the Dimensions of a Social Content Management Framework," Int. J. Adv. Sci. Eng. Inf. Technol., vol. 8, no. 2018, pp. 1850-1857, 2018.

[11] M. R. Gilbert, K. M. Shegda, K. Chin, and G. Tay, "Magic quadrant for enterprise content management," 2011.

[12] Gartner, "Definition of social content," 2017. [Online]. Available: http://www.gartner.com/it-glossary/socialcontent/. [Accessed: 14-Mar-2017].

[13] D. Glazkov, "Social Content Management," 2005. [Online]. Available: https://glazkov.com/2005/03/25/socialcontent-management/. [Accessed: 28-Mar-2016].

[14] J. Spohrer, P. P. Maglio, J. Bailey, and D. Gruhl, "Steps toward a science of service systems," IEEE Comput. Soc., vol. 40, no. 1, pp. 71-77, 2007.

[15] B. Leavy, "Venkat Ramaswamy-a ten-year perspective on how the value co-creation revolution is transforming competition," Strateg. Leadersh., vol. 41, no. 6, pp. 11-17, 2013.

[16] C. K. Prahalad and V. Ramaswamy, "The future of competition: co-creating unique value with customers," Penguin Books India, 2004. 
[17] S. L. Vargo and R. F. Lusch, "Institutions and axioms: An extension and update of service-dominant logic," J. Acad. Mark. Sci., vol. 44, pp. 5-23, 2016.

[18] H. Mohamed et al., "Model Nilai Cipta-Sama dalam Sistem Pengukuran Prestasi," J. Pengur., vol. 45, pp. 155-163, 2015.

[19] C. K. Prahalad and V. Ramaswamy, "Co-creating unique value with customers," Strateg. Leadersh., vol. 32, no. 3, pp. 4-9, 2004.

[20] S. P. Singaraju, Q. A. Nguyen, O. Niininen, and G. Sullivan-Mort, "Social media and value co-creation in multistakeholder systems: a resource integration approach," Ind. Mark. Manag., vol. 54, pp. 44-55, 2016.

[21] C. Bianchi and L. Andrews, "Distribution management consumer engagement with retail firms through social media: An empirical study in Chile," Int. J. Retail Distrib. Manag., vol. 46, no. 4, pp. 364-385, 2018.

[22] C. Oh, Y. Roumani, J. K. Nwankpa, and H. F. Hu, "Beyond likes and tweets: Consumer engagement behavior and movie box office in social media," Inf. Manag., vol. 54, no. 1, pp. 25-37, 2017.

[23] J. W. Creswell, Research Design: Qualitative, Quantitative and Mixed Methods Approaches. London: SAGE Publications Ltd, 2014.

[24] B. E. Munkvold, T. Päivärinta, K. H. Anne, and E. Stangeland, "Contemporary issues of enterprise content management: The case of Statoil,” Scand. J. Inf. Syst., vol. 18, no. 2, pp. 69-100, 2006.

[25] Gartner, "Definition of social media platform," 2018. [Online]. Available: https://www.gartner.com/itglossary/social-media. [Accessed: 14-Mar-2018].

\section{BIOGRAPHIES OF AUTHORS}
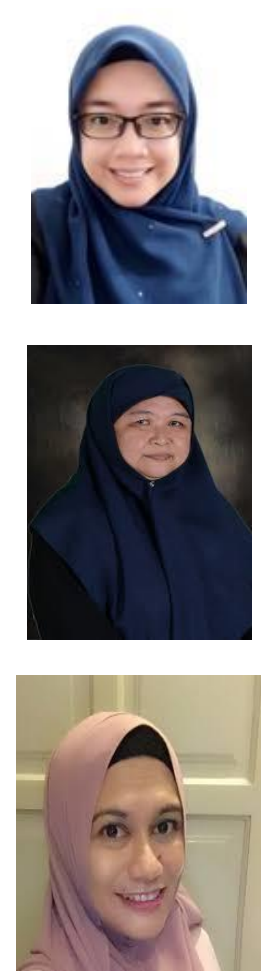

Wan Azlin Zurita Wan Ahmad is a doctoral student at the Centre for Software Technology and Management, Faculty of Information Science and Technology, Universiti Kebangsaan Malaysia (UKM), Malaysia. Her research interests include service science, value and value co-creation, and social content management. She holds a bachelor's degree in information management (software engineering) from Universiti Malaysia Terengganu, Malaysia, and a master in information technology from Universiti Kebangsaan Malaysia, Malaysia. She is currently employed as ICT Expert/Principal Assistant Director in Malaysia Government.

Muriati Mukhtar is an associate professor at the Centre for Software Technology and Management, Faculty of Information Science and Technology, Universiti Kebangsaan Malaysia (UKM), Malaysia. She is currently the Head of the Agent Mediated and Service Science research lab in UKM. Her current research interests are service science, supply chain simulation and applications of information technology in small and medium enterprises.

Yazrina Yahya is an associate professor who specializes in the area of Information Technology and Internationalization of Higher Education. She has been with Universiti Kebangsaan Malaysia since November 1997 and is currently based at Faculty of Economics and Management. Her multidisciplinary interest is due to her vast experience as the Director of the International Relations Centre, UKM and also because of her links to industry. Her major specializations are in the areas of Service Science, Information System Development, and Internationalization of Higher Education. 